\title{
COMPARISON OF ELASTIC WAVE VELOCITIES USING DOWNHOLE AND SUSPENSION TECHNIQUES
}

\author{
Takeshi KAMEI*, Jun OTANI** \\ and Yoshihiro NAKAMURA***
}

\begin{abstract}
Two different seismic borehole techniques are compared in this paper: One is a common downhole method with the source at the ground surface and the receiver in the downhole, and the other is a technique called suspension method in which both the source and the receiver are on the single sonde in a borehole. P-wave and S-wave velocities are compared between these test results using the same borehole. In addition, the downhole method is used to measure the damping with a reference seismometer near the surface. A cyclic torsional shear test and ultrasonic pulse test are also performed on undisturbed samples in order to compare the in-situ test results with those in laboratory. To this end, the writers summarize the comparisons of elastic wave velocities generated by in-situ measurements and laboratory tests. Direct application of these test results to the other fields will require further research.

Key Words : in-situ test, geophysical exploration, dynamic, test procedure, test equipment
\end{abstract}

\section{INTRODUCTION}

Seismic methods have been carried out to evaluate in-situ dynamic soil properties, such as Young's modulus and shear modulus as well as damping ratio, by measuring $\mathrm{P}$ - and S-wave velocities and the amplitudes of these waves. Although there are many techniques to measure the in-situ $\mathrm{P}$ - and $\mathrm{S}$-wave velocities, downhole method and suspension method have been most often conducted in Japan.

In the downhole method, the wave is generated at the ground surface and it is received in the borehole at different depths. This method is one of the most popular techniques because of its simplicity and low cost (Auld 1977; Imai 1977; Wood 1986). A $\mathrm{P}$-wave is generated by hitting the ground surface vertically while a $S$-wave is generated by striking a plank horizontally with a wooden hammer as shown in Fig.1. Both wave velocities are calculated by measuring the traveling time at the receiver in the borehole at the various depths.

* Dr.Eng., Chief Research Engineer, Kiso-Jiban Consultants Co. Ltd., 1-11-5, Kudan-kita, Chiyoda-ku, Tokyo 102, Japan.

** Ph.D, Research Associate, Department of Civil Engineering (Suiko), Kyushu University.

*** M.Eng., Chief Research Engineer, Kiso-Jiban Consultants Co.Ltd.

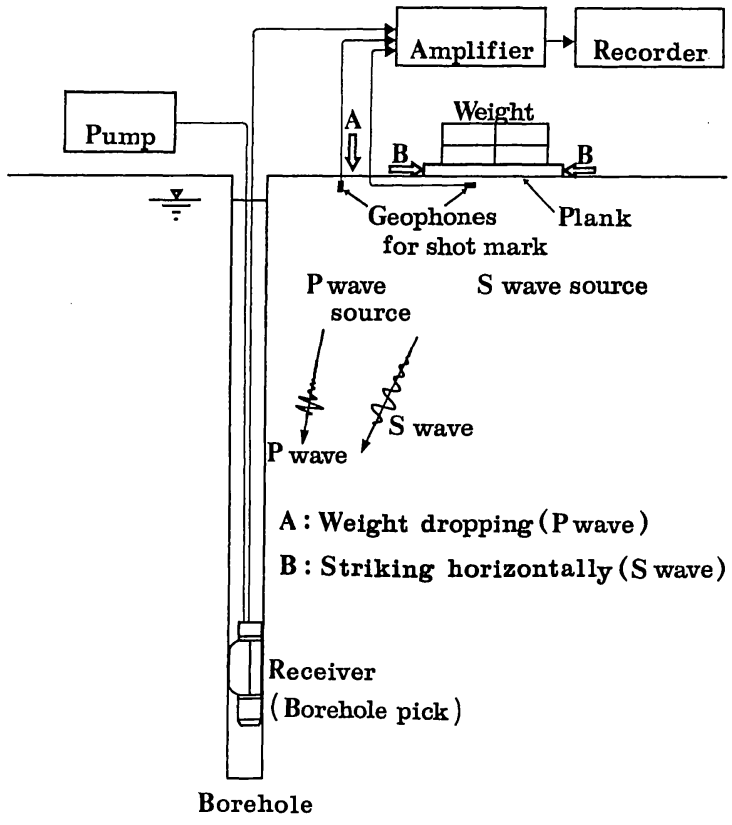

Fig. 1 Downhole method.

Suspension method is relatively new compared with the downhole method. Details of the method used have been presented elsewhere (Kitsunezaki 1980 and 1983). 


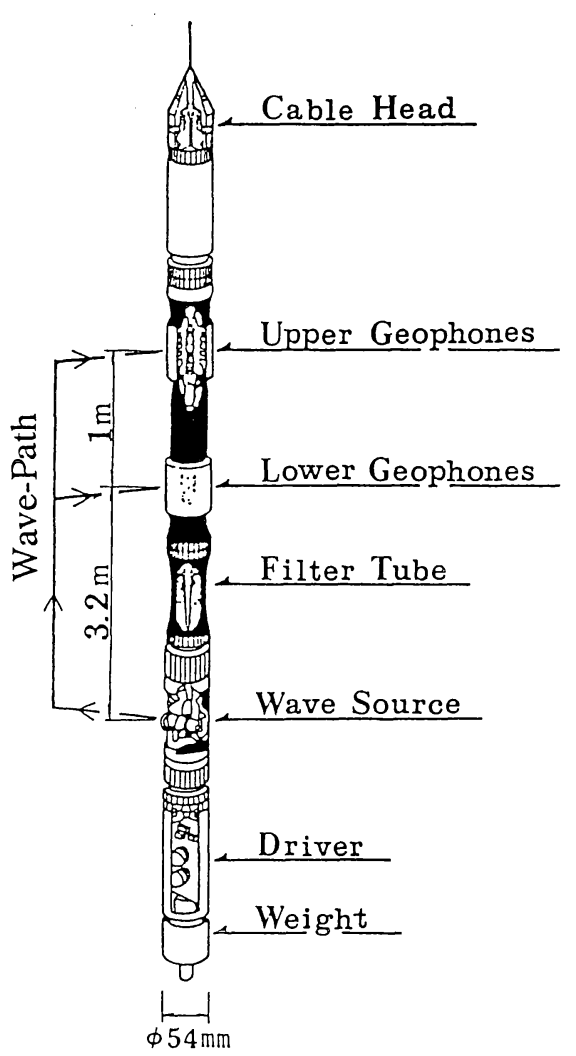

Fig. 2 Sonde of suspension PS-logging.

Fig.2 shows a revised sonde of the suspension PS-logging (Oyo, 1988). Two geophones and vibration source are built in a single sonde. An excitation force is applied to the sonde suspended in the borehole fluid and the travel times of both waves are measured by both the upper and lower geophones. This method is especially effective for the cases where wave generation cannot be conducted at the ground surface and where $\mathrm{S} / \mathrm{N}$ ratio(signal to noise ratio) cannot be improved. Besides, the waves with high frequency are operated in the method, so that quick measurement and less effects of the ground vibration are expected. Meanwhile, the waves are transmitted in the borehole liquid, in which the vibration force is applied in the horizontal direction, so that $\mathrm{P}$ - and $\mathrm{S}$ wave velocities beyond the groundwater level are not capable of measuring in the ground.

Although these PS-logging methods have been widely conducted in order to evaluate $\mathrm{P}$ - and S- wave velocities, comparative studies of downhole method with suspension method are relatively few( Kokusho 1986; Ohya 1986). It is also important to investigate a correlation of these properties obtained from in-situ measurements with properties observed in laboratory tests. For the response analysis of the ground vibration due to earthquakes or other vibrating foundations, it is important to evaluate in-situ condition on material properties. These properties strongly affect the nonlinear response analysis of ground and foundations (Schnabel et.al. (1972) and Otani (1990)).

The purpose of this paper is to compare the elastic wave velocities using downhole and suspension techniques. In addition, the correlation of the in-situ measurements with laboratory test results, such as cyclic torsional shear and ultrasonic pulse tests, is also investigated.

\section{SUMMARY OF MEASUREMENTS}

The soil profile at the investigation site located in Chiba Prefecture, which was diluvial deposit shown in Fig.3, consists of layered loams of volcanic cohesive soil underlain by layered sandy soils. The groundwater level was 11 meter from the ground surface. Two different seismic methods was carried out using the same borehole at the site. One is a downhole method, in which both $\mathrm{P}$ - and S-wave velocities are obtained by measuring the traveling time at the receiver in the borehole at various depths. In addition, another borehole of one meter depth was also used in order to obtain a Q-factor of damping characteristic by measuring the damping of $\mathrm{S}$-wave. The Q-factor was obtained by the difference of the amplitudes at these two boreholes and, here, the geometrical damping was excluded from the total damping characteristic. The other is suspension method. In this method, as mentioned before, the waves are transmitted the borehole liquid, in which one vibration source and two geophones are built in a single sonde. The $\mathrm{P}$ - and $\mathrm{S}$-wave velocities are obtained by measuring the vertical and horizontal components of the vibration, respectively using these two geophones. It is noted that these velocities cannot be measured for the depths of less than $12 \mathrm{~m}$ because of the unsaturated condition above the groundwater level. 


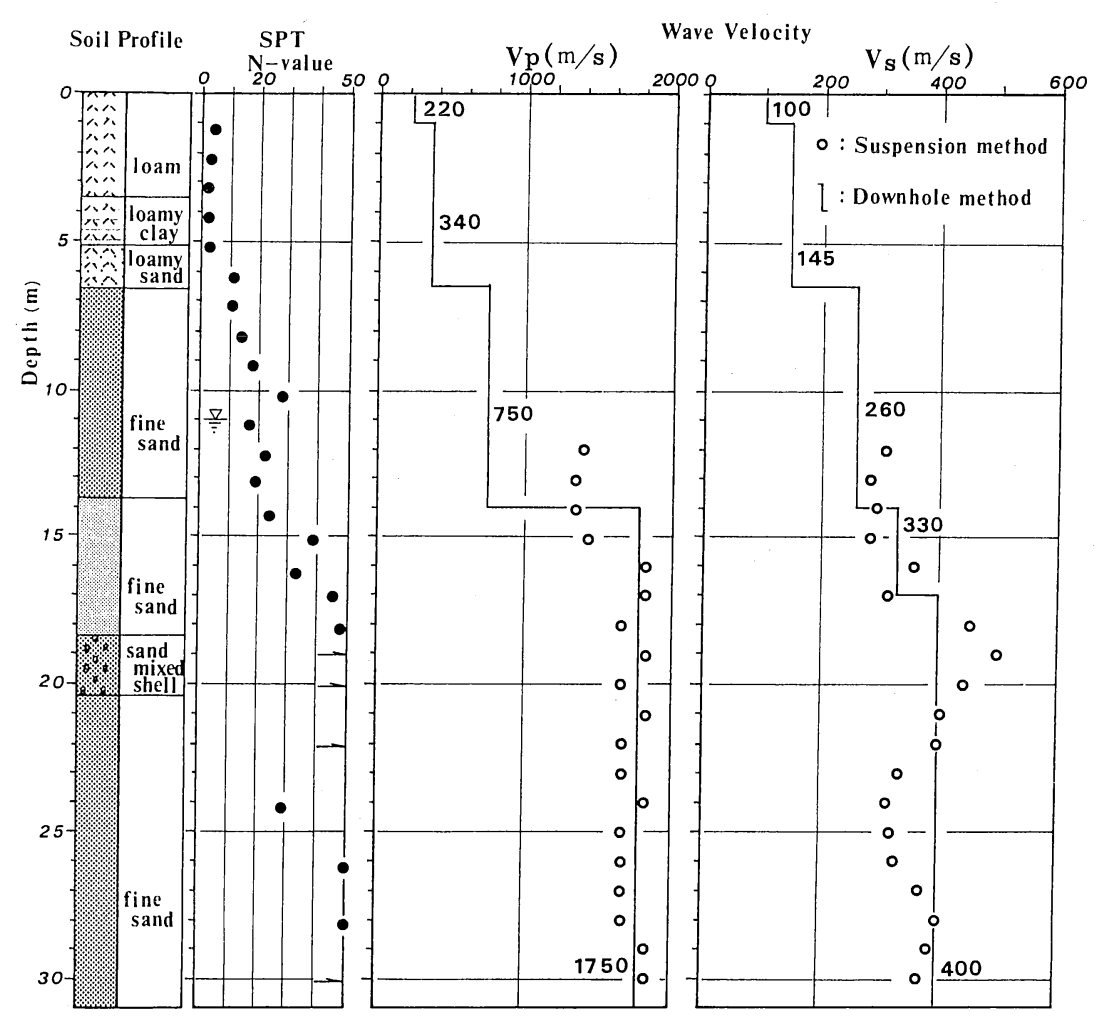

Fig. 3 Soil profile and PS logging test results at the investigation site.

In order to investigate the correlation of in-situ measurements with laboratory test results, cyclic torsional shear tests and ultrasonic pulse tests were also carried out in laboratory using undisturbed soils sampled at the investigation site. In the cyclic torsional test, torsional displacement with the frequency of $1 \mathrm{~Hz}$ was applied to a hollow soil specimen and the relationship of shear stress against shear strain was obtained. For the ultrasonic test, an impulse source with the frequency of $5 \mathrm{kHz}$ was applied at the top of the soil specimen for the measurement of Pwave velocity, while an impulse source of $100 \mathrm{kHz}$ is applied for the measurement of Swave velocity. The travel times of both $\mathrm{P}$ and $S$-waves from the top to the bottom of the specimen were measured to calculate both the velocities. The amplitudes of these propagated waves were infinitesimal, so that these signals generated by the waves were amplified by applying the sources repeatedly one hundred times.

\section{RESULTS AND DISCUSSIONS}

Soil profile at the investigation site and the results of both downhole and suspension methods are summarized in Fig.3. Loam deposits extended to a depth of approximately $6 \mathrm{~m}$ from the ground surface. The N-value (obtained by Japanese Standard of SPT with hammer weight of $63.5 \mathrm{kgf}$, falling height of $75 \mathrm{~cm}$ and effective penetration of $30 \mathrm{~cm}$ ) was approximately 3 in this deposit. For the ground beneath the loam deposits, different types of sand deposits were observed. These sand deposits are classified as diluvial deposits, in which the $\mathrm{N}$-values vary between ten to fifty.

In the PS-logging tests, travel times were obtained by means of observing the wave forms. These are shown in Figs. 4 and 5 for both the methods, respectively. $\mathrm{P}$ - and $\mathrm{S}$ wave velocities are calculated by using the distance and time of the traveling waves. 
(a) P wave

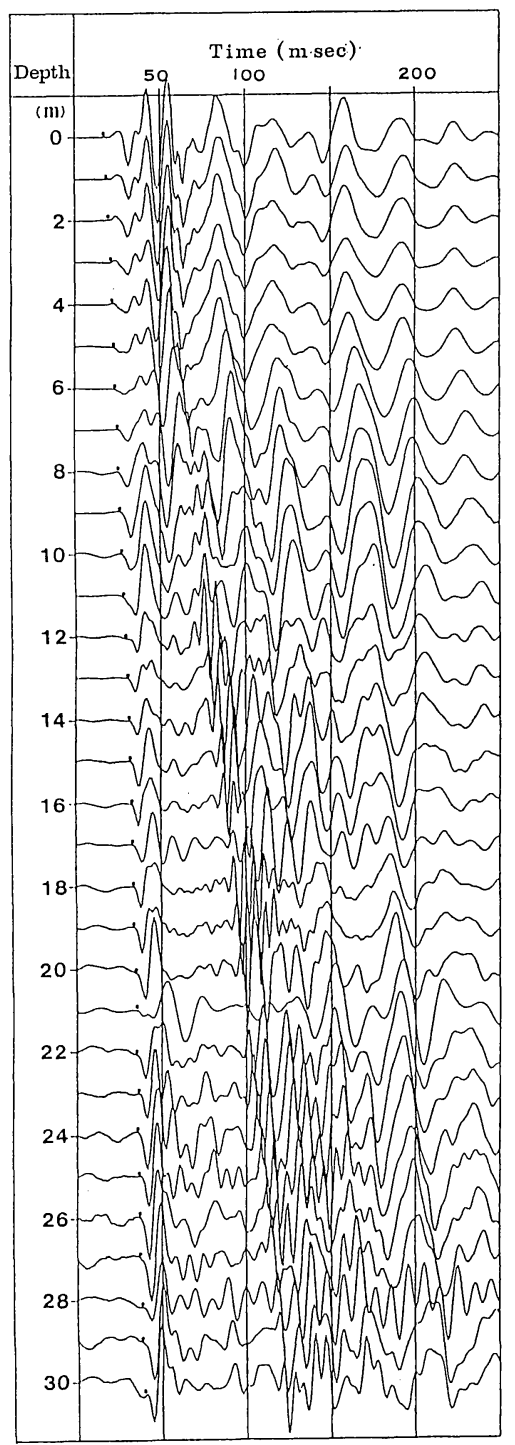

(b) S wave

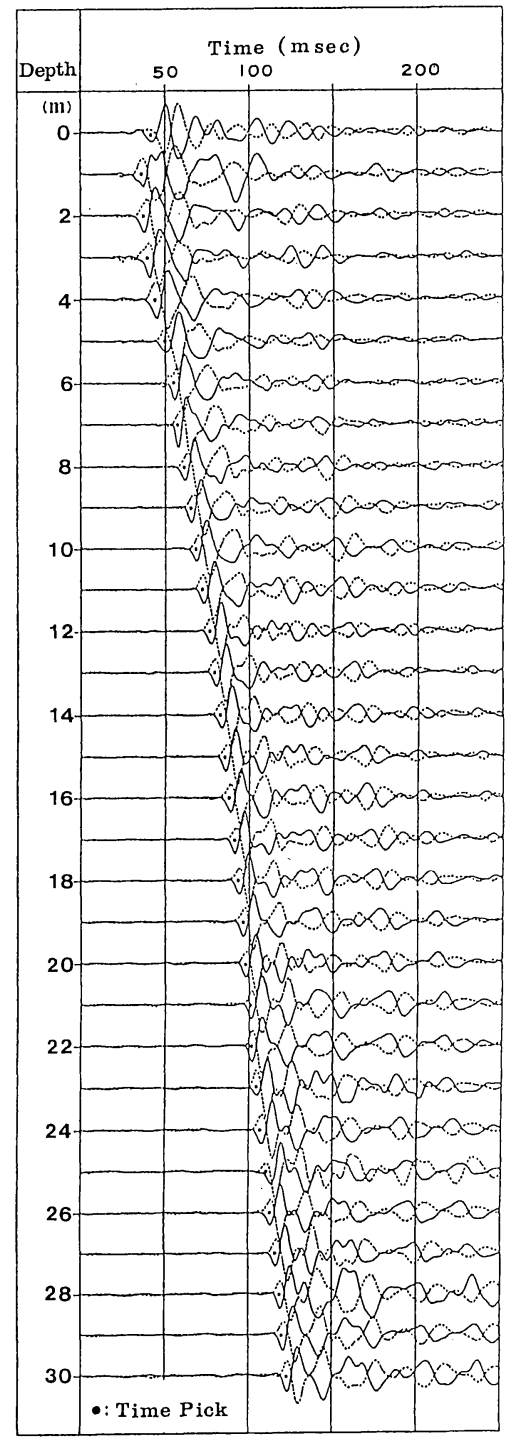

Fig. 4 Waveform records by downhole method.

For the downhole method, although it is commonly determined the average S-wave velocity, the velocity in every $1 \mathrm{~m}$ depth was also calculated for the purpose of the comparison with the results of suspension method. S-wave velocity was calculated by using time-distance curves shown inFig.6(a) in each depth. Because of using the plank hammering method for generating the Swave, the frequency of the wave is relatively low, approximately $40-50 \mathrm{~Hz}$. Therefore, the origin of the wave is not clear and an artificial error occurs in the measurements of the travel time. Besides, it seems that this error affects strongly for high value of $\mathrm{S}$ wave velocity. Thus, in order to minimize this error, the average value of $\mathrm{S}$-wave velocity in each selected intervals determined by using mean gradient of the time-distance curve was obtained. For the measurement of $\mathrm{P}$-wave velocity, the average value was also obtained. The distributions of average values of $S$-wave velocities in the ground are shown in Fig.6(b) with the velocities at every $1 \mathrm{~m}$ depth. The difference between these two results is large as the value of the velocity becomes large. The same results for the suspension method are shown in Fig.7(a) and 
[Waveform Records] Upper
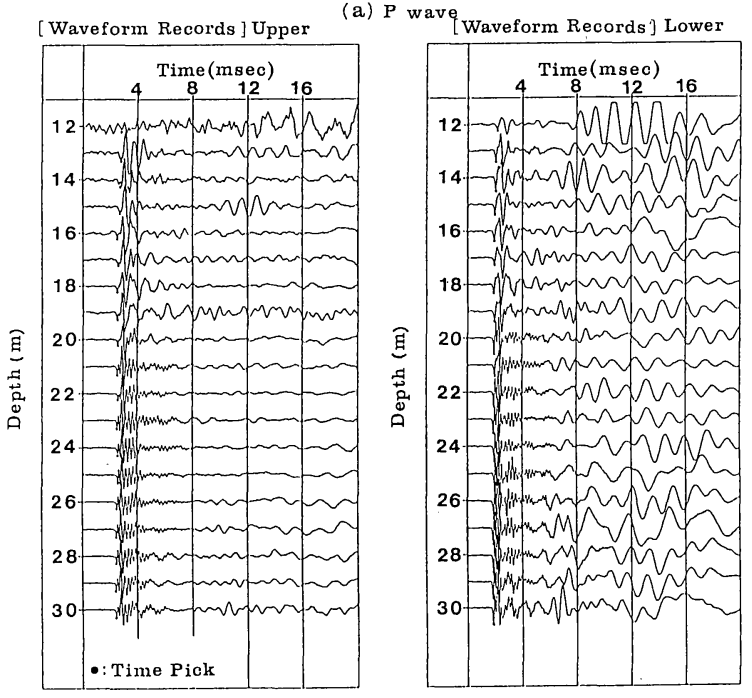

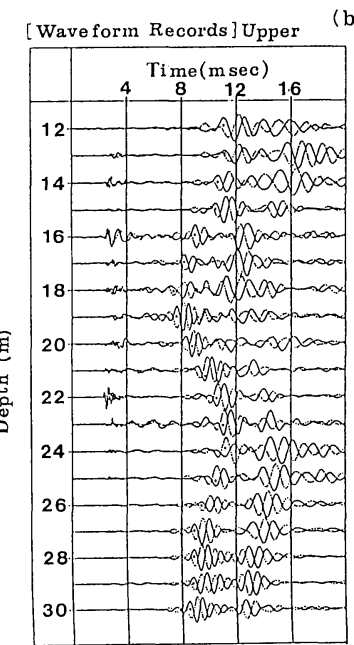

(b) S wave [Waveform Records] Lower

Fig. 5 Waveform records by suspension method.

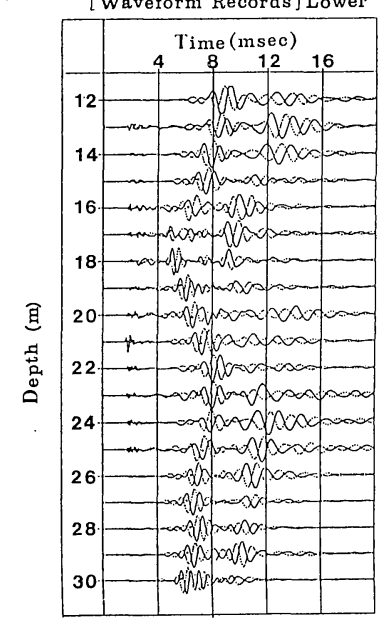

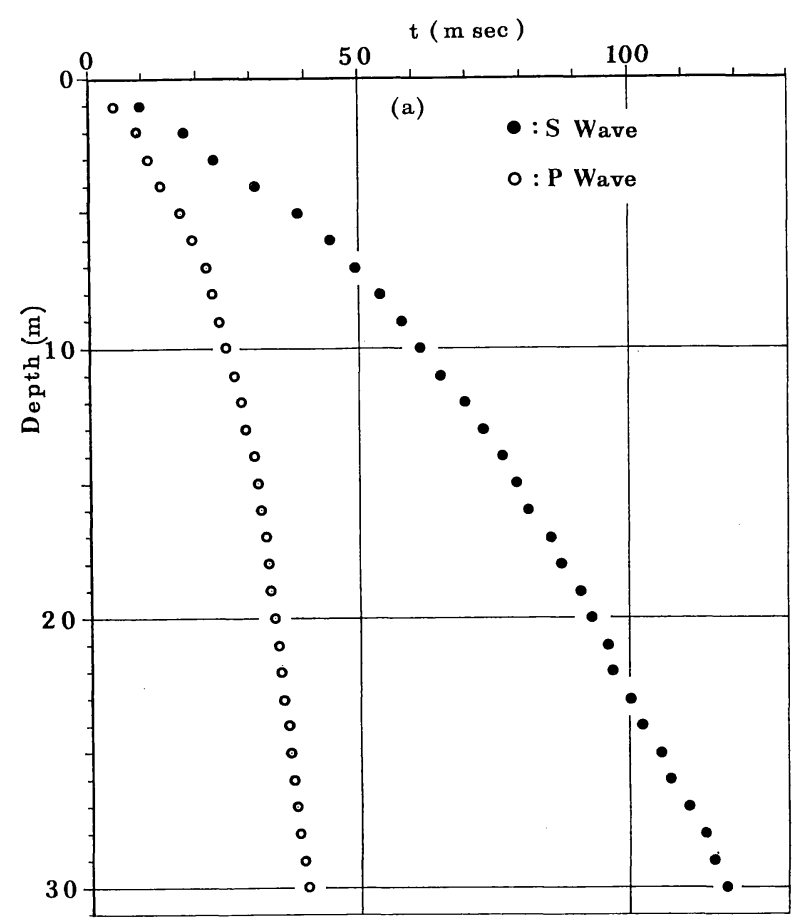

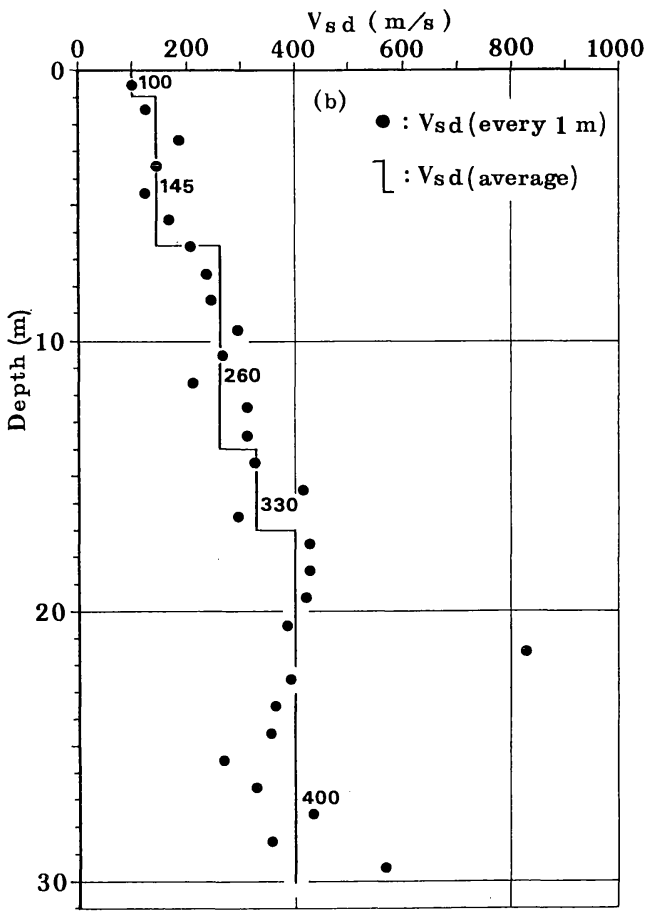

Fig. 6 (a) Time-distance curve and (b) distribution of $S$ wave velocity by downhole method. 

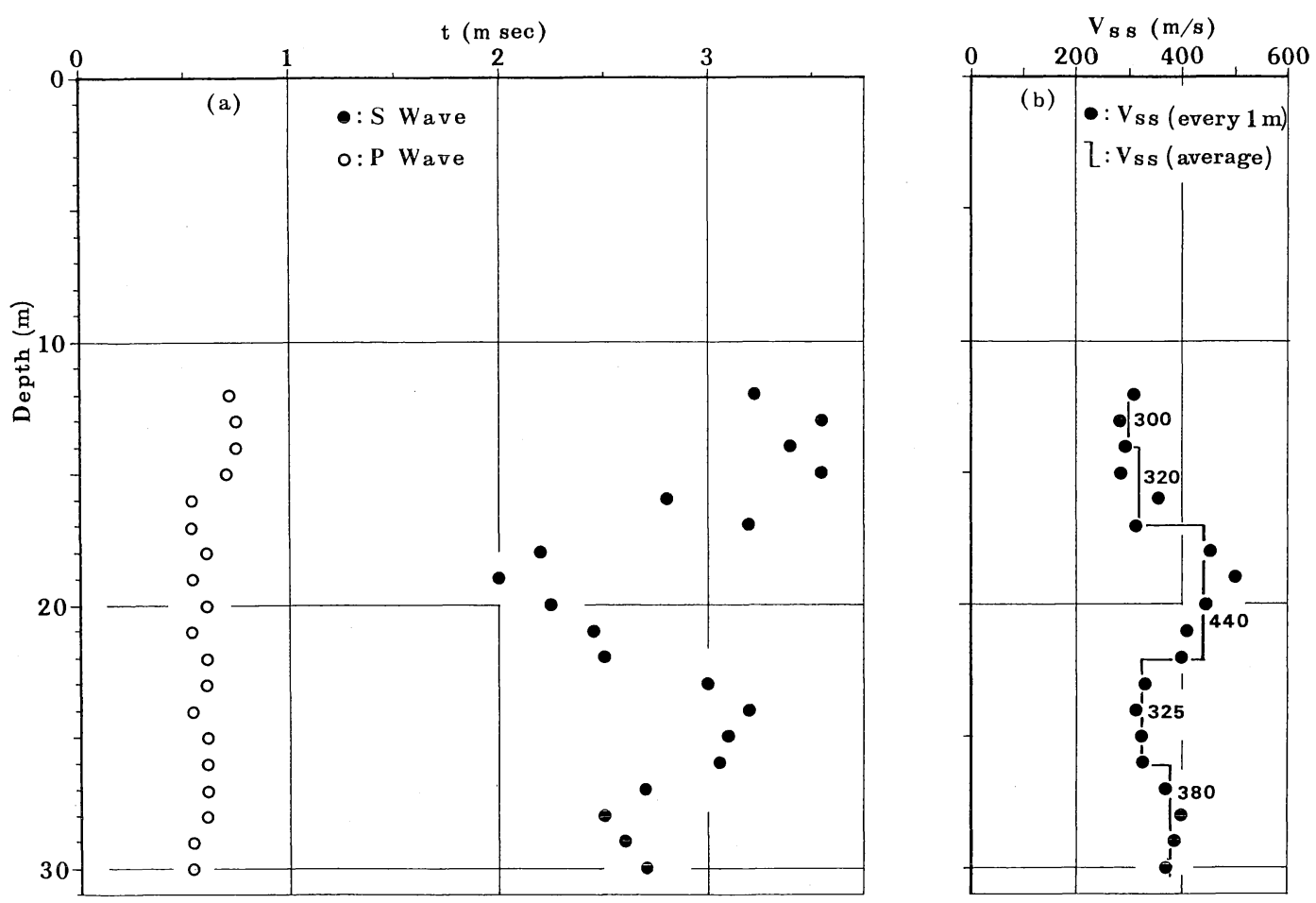

Fig. 7 (a) Time-distance curve and (b) distribution of $\mathrm{S}$ wave velocity by suspension method.

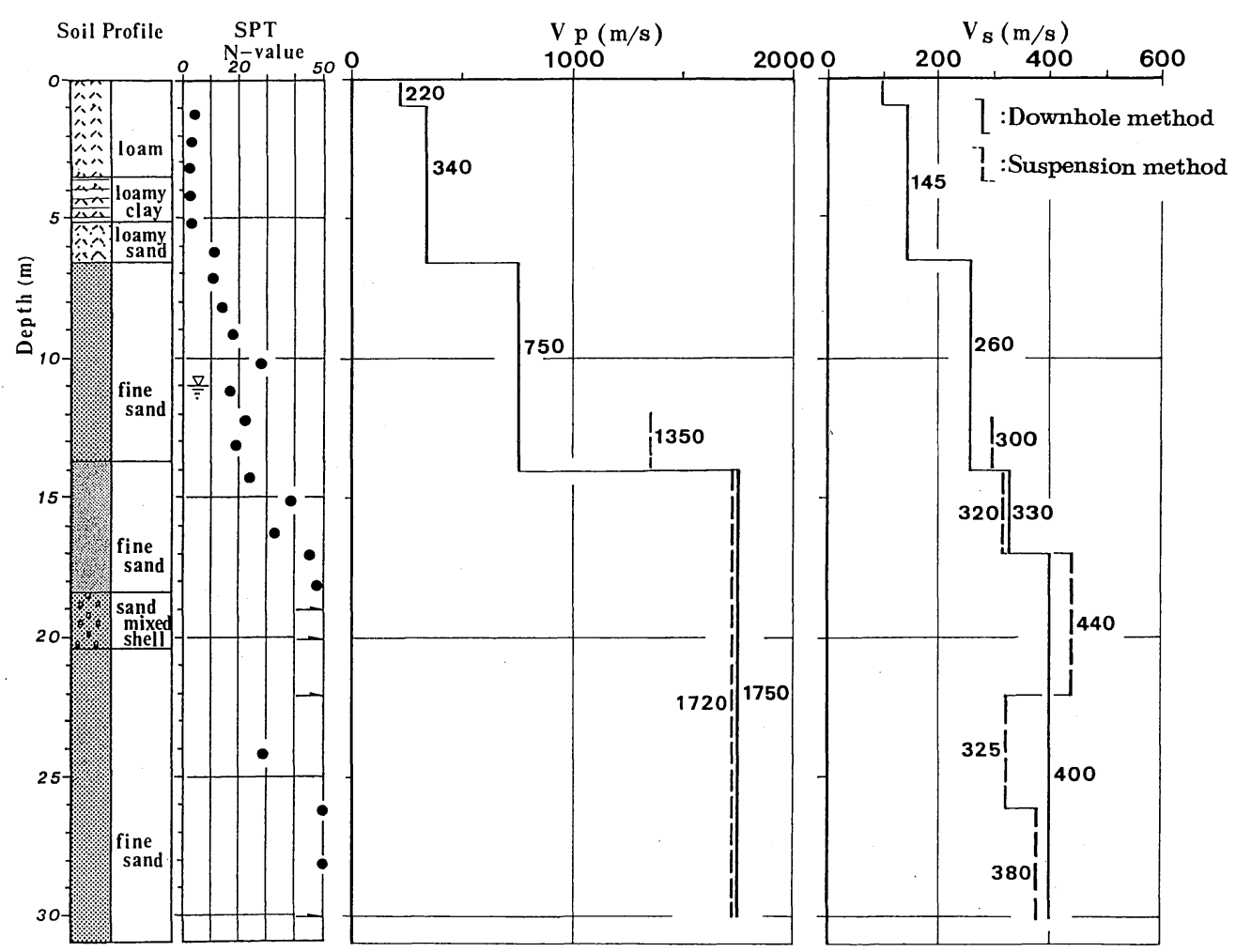

Fig. 8 Comparisons of average $\mathrm{P}$ and $\mathrm{S}$ wave velocities between downhole and suspension methods. 


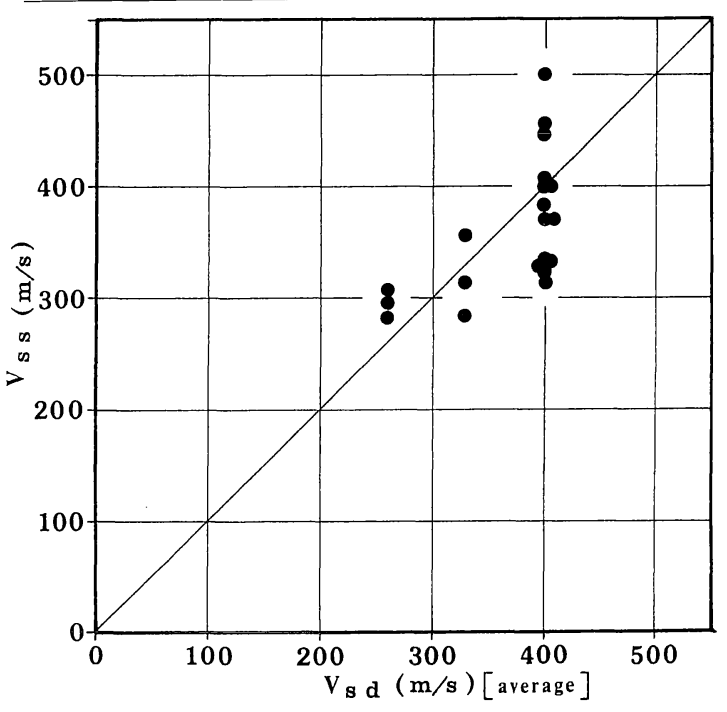

Fig. 9 Correlation of average $S$ wave velocities

(b). According to the results shown in Fig.7(b), the average value of $S$-wave velocities gives more precise distribution of the wave velocity compared to the results by the downhole method. In addition, the Swave velocity generated by suspension method is closely related to a distribution of $\mathrm{N}$-value of the ground.

Fig. 8 shows the comparisons between both average values of $\mathrm{P}$ - and $\mathrm{S}$-wave velocities from both downhole and suspension methods, respectively. P-wave velocity by suspension method agrees with that by the downhole method for the depth of more than $15 \mathrm{~m}$. On the other hand, S-wave velocity by suspension method makes precise subdivision possible compared to the use of the wave velocity by downhole method because the wave velocity by suspension method is well correlated to the distribution of $\mathrm{N}$-value in the ground. The correlation between both the average $S$-wave velocities by downhole and suspension methods is plotted in Fig.9. There are some variations among these results. But both velocities agree fairly well in each other. The correlation of S-wave velocity in every $1 \mathrm{~m}$ depth in the ground by downhole method with that by suspension method is also shown in Fig.10. Although there is also some scatter in the figure, the correlation by using the velocities in every $1 \mathrm{~m}$ depth is admitted to the same trend.

Fig.11 shows the relation between S-wave velocity and $\mathrm{N}$-value. Here, the velocity by

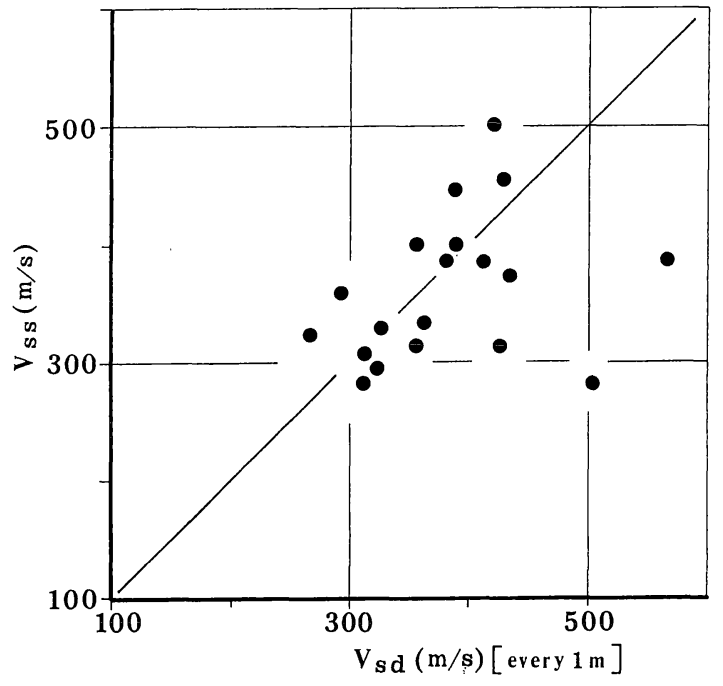

Fig. 10 Correlation of $S$ wave velocities in every $1 \mathrm{~m}$ interval between downhole and suspension methods.

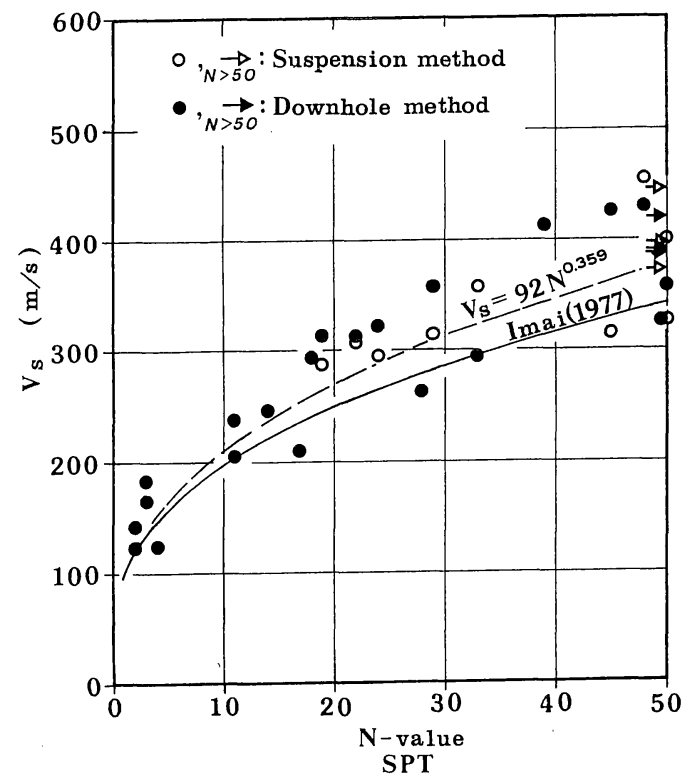

Fig. 11 Relationship between $S$ wave velocity and $\mathrm{N}$ value.

downhole method is the one in every $1 \mathrm{~m}$ depth. The velocities obtained from both the methods are gradually increased with increasing the $\mathrm{N}$-value. Imai (1977) has proposed following equation for this relation:

$$
\mathrm{Vs}=91 \mathrm{~N}^{0.337}
$$




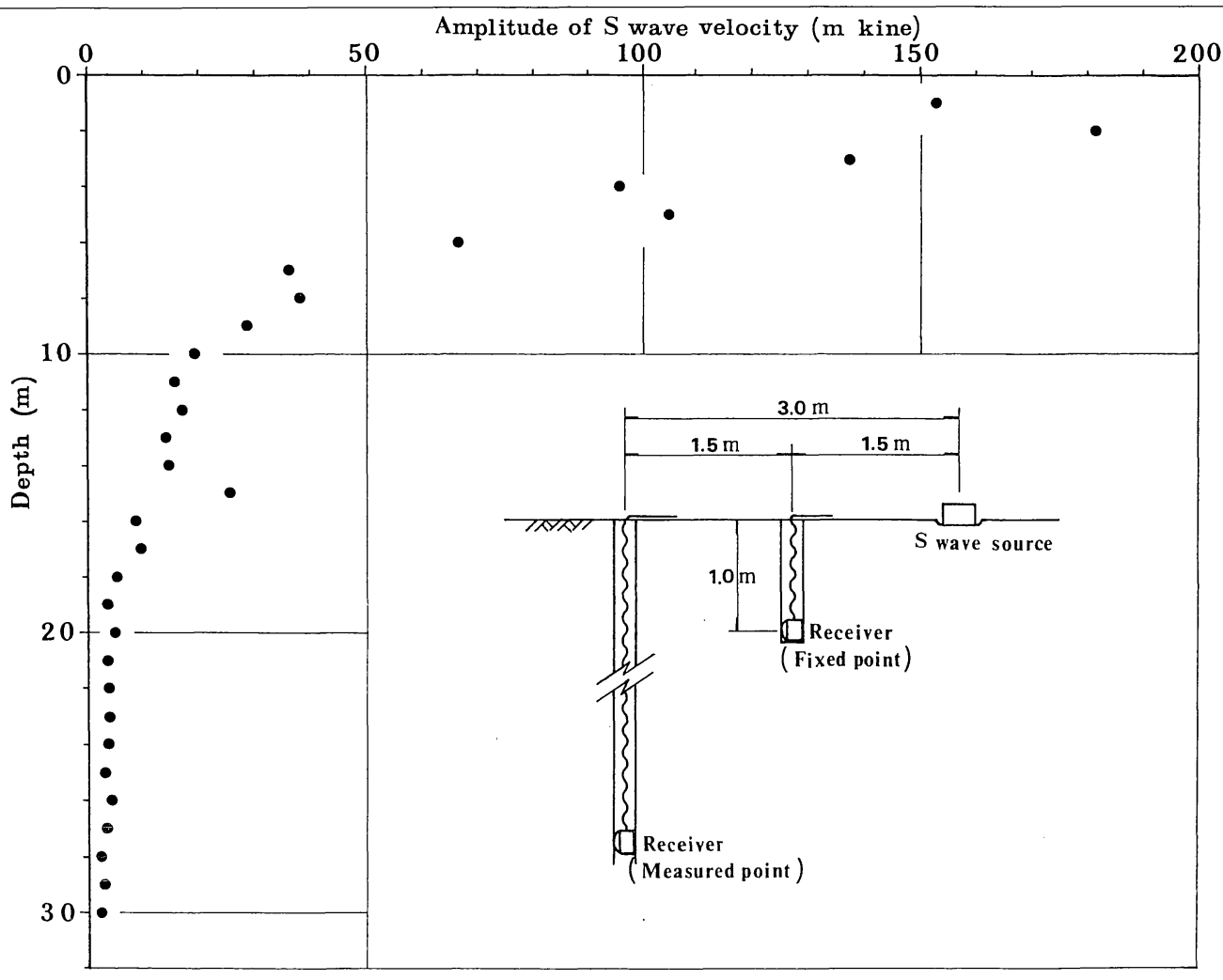

Fig. 12 Distribution of amplitude of S wave velocity with its depth.

When the same form as Eq.(1) is applied to the results here in this field, following equation is obtained by conducting regression analysis:

$$
\mathrm{Vs}=92 \mathrm{~N}^{0.359}
$$

These equations are drawn in Fig.11 and as far as the results here in the site is concerned, the equation proposed by Imai may be realized as a lower limit values in this field.

Damping characteristic of soil is also verified as a Q-factor (Quality factor) for the downhole method. The definition of the Qfactor is shown as

$$
\mathrm{Q}=2 \pi \mathrm{E} / \Delta \mathrm{E}
$$

where $\mathrm{E}$ is a maximum strain energy stored in each cycle of the vibration and $\Delta \mathrm{E}$ is an internal energy for that cycle. The soil damping is defined as the decrease of the amplitude of the $\mathrm{S}$-wave, in which the observed values are normalized by the amplitude at 1.0 meter depth in a shallow monitoring borehole shown in Fig.12. This damping includes both geometrical and material dampings. The amplitude decreases quickly to that of $10 \%$ at the depth of $10 \mathrm{~m}$ and even to the value of $1 \%$ at the depth of $30 \mathrm{~m}$. In order to calculate the Q-factor, the damping of each frequency component is obtained by spectrum analysis of the traveling wave as shown in Fig.12. The distributions of the first dominant frequency as a function of depth are shown in Fig.13. The dominant frequency measured in each depth of the borehole decreases as the depth increases, but it stays around $62 \mathrm{~Hz}$ at the fixed point in the shallow monitoring borehole. Q-factor was obtained by using the logarithmic value of the ratio between both the frequencies at two boreholes by subtracting the geometrical damping. The internal damping of soil is plotted against frequency as shown in Fig.14. The damping factor $h$ is related to the Q-factor as

$$
\mathrm{h}=1 /(2 \mathrm{Q}) \text {. }
$$




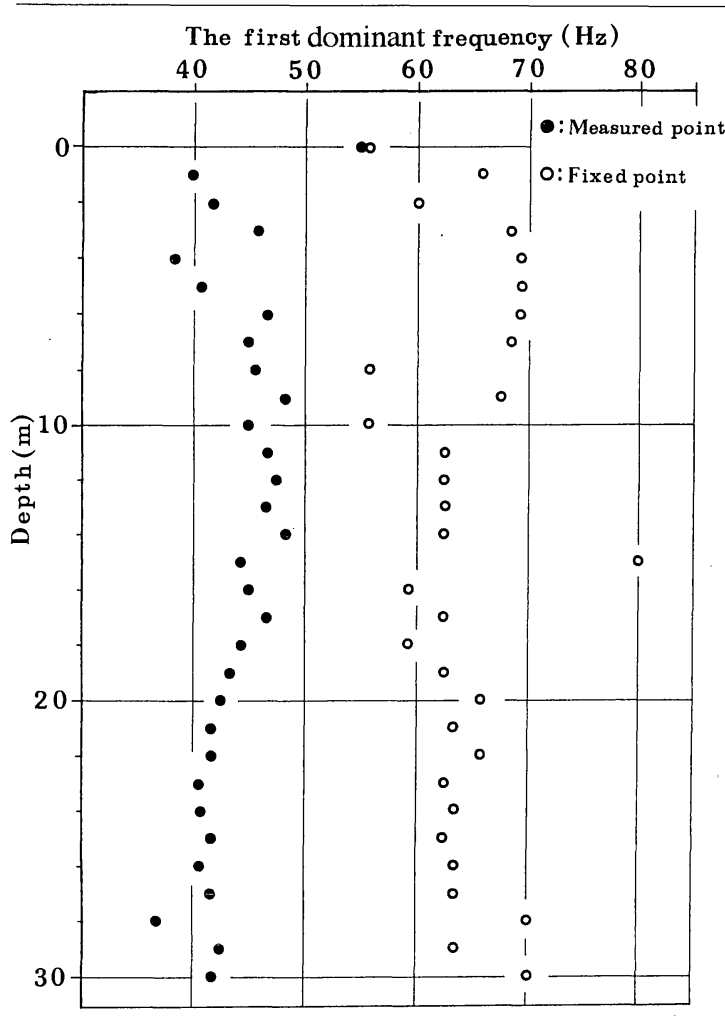

Fig. 13 Distribution of first dominant frequency with its depth.

It is noted that the radiation damping is calculated by the density of the soil, S-wave velocity and the traveling distance under the assumption of the homogeneous condition for the multi-layered ground. When dynamic response of ground vibration is analyzed, the average damping value in each layer or total ground is indispensable(Otani 1990; Schnabel et al. 1972). Fig.14(a) shows the average value of damping characteristic for depths of 7 - 30m. The Q-factor in each frequency is distributed between 18 and 28 and the average value is 21.7 while the damping factor $h$ is $2.3 \%$. Fig.14(b) shows the same average value at the depth of $7-14 \mathrm{~m}$ and these values vary from 2 to 120 against change of frequency. According to these results shown in Fig.14, the in-situ damping characteristic is affected by the investigated subdivision of the ground. Considering the condition of in-situ measurements of dynamic soil properties, these in-situ dampings may be evaluated as the values at the small strain level.

For the laboratory dynamic tests, undisturbed samples of loam and sand were obtained at the same site where the PS-
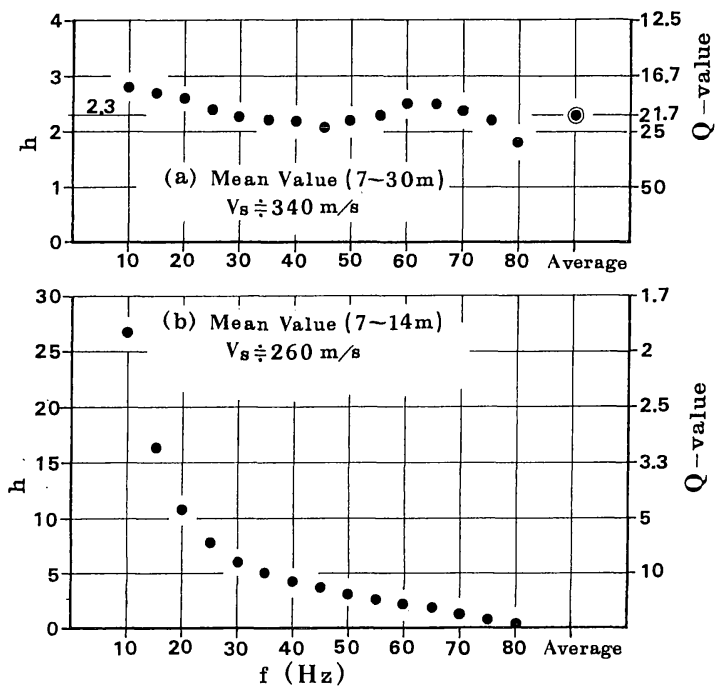

Fig. 14 Relationship between internal damping and frequency.

logging tests were conducted. Sampling was carried out by using triple tube sampler (Mori 1986) in order to obtain the high quality samples. Both cyclic torsional shear and ultrasonic pulse tests were carried out using these undisturbed soils. In the torsional test, the hollow samples were $10 \mathrm{~cm}$ in height, $3 \mathrm{~cm}$ inside diameter, and $7 \mathrm{~cm}$ outside diameter. The test was conducted after isotropic consolidation and the confining pressure was chosen as the same value as the effective overburden pressure at the site. A sinusoidal wave was applied with the frequency of $1.0 \mathrm{~Hz}$ and the amplitude of the wave changes from infinitesimal strain level $\left(\gamma \fallingdotseq 1.0 \times 10^{-5}\right.$ : loam and $\gamma \fallingdotseq 6.0 \times 10^{-6}$ : sand ) to a large strain level in every 11 cycles. Fig.15 shows the variations of the shear modulus $\mathrm{G}$ and the damping factor $\mathrm{h}$ against the various strain levels based on these two kinds of undisturbed soil samples. The shear modulus of sand at the small strain level is obviously large compared to that of loam. For the variation of the shear modulus due to the strain level, it is quickly decreased for sand while that for loam shows not much difference. The damping factor $h$ at the small strain level for both sand and loam are relatively close to each other, but the damping of sand is approximately twice as large as that of loam for increasing the strain level. This damping factor at small strain level based on the laboratory tests is as small 


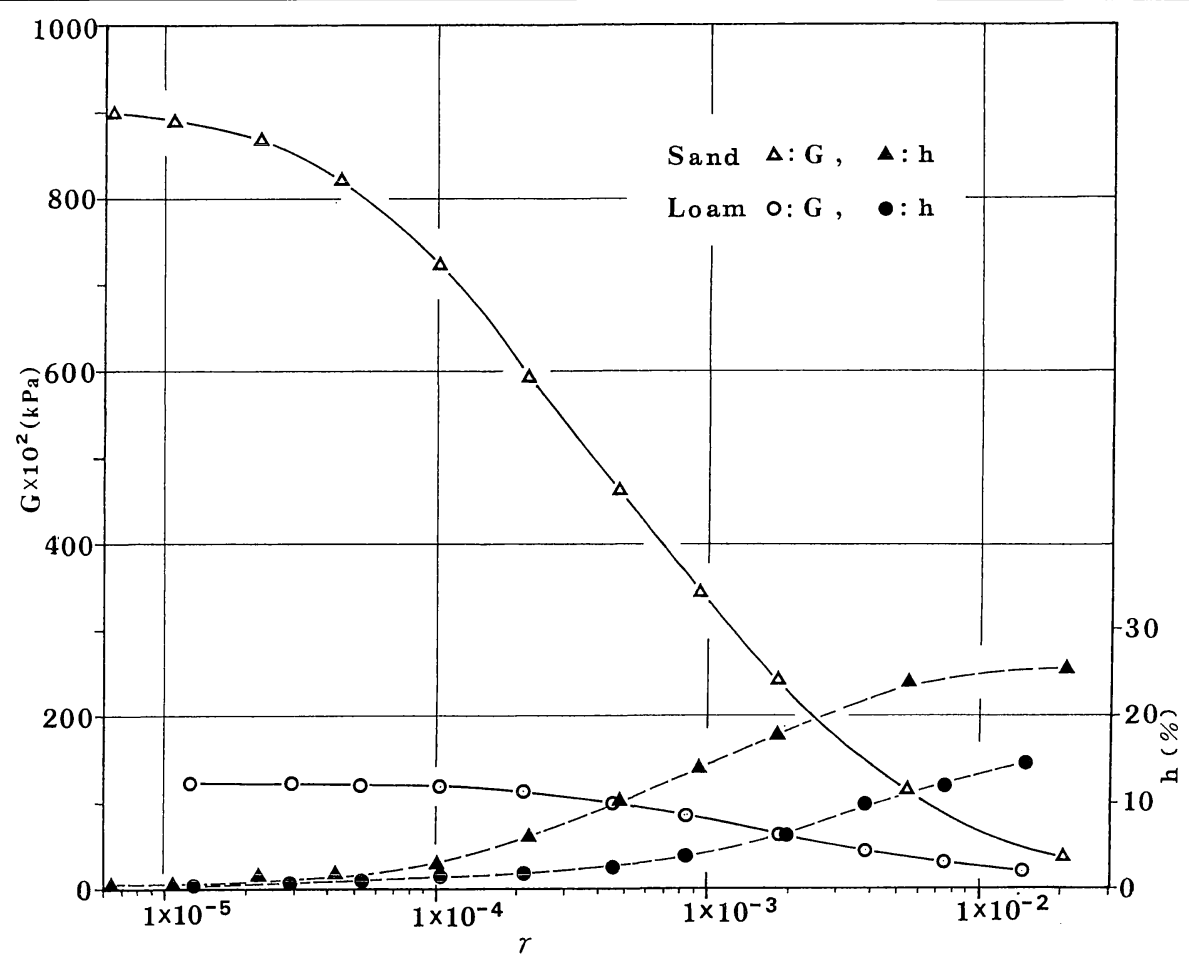

Fig. 15 Shear stain-dependent properties of shear modulus and damping ratio in cyclic torsional shear tests.

Table 1 Physical properties of sampling soils and the test results of ultrasonic pulse test.

\begin{tabular}{|c|c|c|c|c|c|c|c|c|c|c|}
\hline $\begin{array}{c}\text { Soil } \\
\text { Sample }\end{array}$ & Depth(m) & G s & Sand $(\%)$ & Silt (\%) & Clay(\%) & $\omega_{n(\%)}\left(V_{p}(\mathrm{~m} / \mathrm{s})\right.$ & $V_{s}(\mathrm{~m} / \mathrm{s})$ & $\gamma_{\mathrm{t}\left(\mathrm{kN} / \mathrm{m}^{3}\right)}$ & $\sigma_{\mathrm{c}}(\mathrm{kPa})$ \\
\hline \multirow{2}{*}{ Loam } & 2.8 & 2.716 & 18 & 60 & 22 & 133 & 495 & 101 & 13.36 & 40 \\
\hline \multirow{2}{*}{ Sand } & 7.8 & 2.693 & 0.0025 & 0.2118 & - & 26 & 626 & 202 & 19.16 & 110 \\
\hline
\end{tabular}

as less than $1.0 \%$ and this is much smaller than that by using Q-factor based on in-situ measurements.

The ultrasonic pulse test was also conducted using triaxial cell and the traveling waves in the specimen were observed by ultrasonic transducer at the bottom of the specimen. The details of the test method have been discussed by Kokusho (1986). The results of the ultrasonic test are summarized in Table 1 with the physical properties of the undisturbed soil specimen. It is assumed that these results be almost the same values as those of in-situ tests. It is noted here that the ultrasonic test be available for the soil with the characteristic of relatively small radiation damping because of the restriction of the force amplitude. The S-wave velocity obtained by the ultrasonic test is slightly smaller than that by in-situ measurement. It may be considered for this reason that the soil is sampled with some disturbance and that test condition of the confining pressure is different from the mean effective stress at the site.

The correlation of the shear modulus by in-situ measurement with that in the laboratory test at small strain level is shown in Fig.16. Although not many test results are plotted in the figure, the in-situ value is slightly larger than that in the laboratory. It may be concluded that this difference be caused by sample disturbance and the test conditions and also become negligible for the soil sample with relatively dense condition of the ground. 


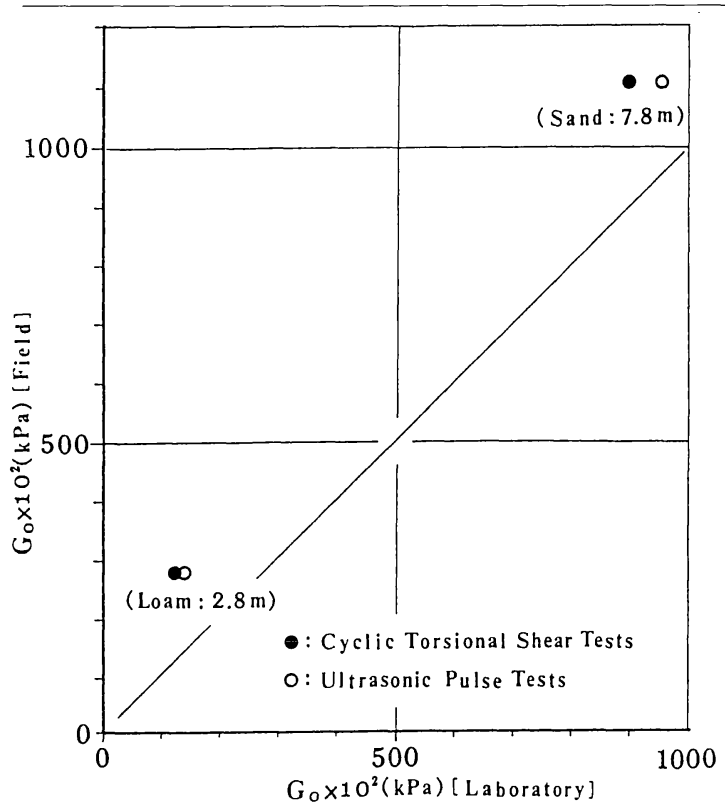

Fig. 16 Correlation of shear modulus at infinitesimal strain level between laboratory and in-situ tests.

\section{CONCLUSIONS}

The P- and S-wave velocities were measured by not only downhole method but also suspension method using the same borehole at the site. These in-situ values were compared with the results obtained from laboratory. The conclusions drawn from the discussion in the present paper are summarized as follows:

(1) Although the frequency of S-wave in the downhole method is relatively low (approximately $40-50 \mathrm{~Hz}$ ), when the average value of the velocities generated by downhole method is taken into account, it agrees with that obtained by suspension method.

(2) The distribution of S-wave velocity in every $1 \mathrm{~m}$ depth based on the suspension method is well correlated with that of $\mathrm{N}$ value in the ground. The suspension method is more accurate than the downhole method because of using high frequency of the waves. Therefore, more accurate dynamic response analysis of the ground can be conducted by using these results based on the suspension method. But the wave velocity above the ground water level cannot be measured by suspension method. It should be mentioned here that direct application of these results to the other fields will required further research.

(3) Shear modulus at small strain range $(\gamma \leq$ $\left.1.0 \times 10^{-5}\right) \mathrm{G}_{0}$ obtained by both cyclic torsional shear and ultrasonic pulse tests are in good agreement. However, the in-situ value is slightly larger than that in the laboratory.

(4) Damping factor $\mathrm{h}$ obtained by in-situ measurement is larger than that in laboratory tests at small strain range $\left(\gamma \doteqdot 1.0 \times 10^{-5}\right)$, so that this difference should be taken into account when the damping ratio by laboratory test is applied in the response analysis.

(5) More precise nonlinear response analysis of the ground vibration can be achieved by using dynamic soil properties based on the suspension method with the same procedure as linear equivalent method by Schnabel et.al. (1972).

\section{REFERENCES}

1) Auld, B. : Cross-hole and downhole Vs by mechanical impulse. Journal of the Geotechnical Engineering Division, ASCE, 103(GT12) : 13811398, 1977.

2) Imai, T. : P- and S- wave velocities of the ground in Japan. Proceedings, 9th International Conference on Soil Mechanics and Foundation Engineering, Tokyo, 2: 257-260, 1977.

3) Kitsunezaki, C. : A new method for shear wave logging. Geophysics, 45 :1489-1506, 1980.

4) Kitsunezaki, C. : Receivers and sources in the suspension type shear wave logging Geophysical Exploration 36(6) : 367-381,1983.

5) Kokusho, T.: In-situ dynamic soil properties and their evaluations. Proceedings, 8th Asian Regional Conference on Soil Mechanics and Foundation Engineering, 2, Kyoto, Japan : 215-240, 1986.

6) Mori, H. : Recent development in sampling of granular soils in Japan. Proceedings, Fourth International Geotechnical Seminar Field Instrumentation and In-situ Measurements, 25-27, November, Nanyang Technological Institute, Singapore :144-150, 1986.

7) Ohya, S. : In situ $P$ and $S$ wave velocity measurement. Proceedings, In situ '86, ASCE Special Conference on Use of In situ Tests in Geotechnical Engineering, Blackburg, VA, ASCE, Geotechnical Special Publication 6,: 1218-1235, 1986.

8) Otani, J. : Nonlinear pile group model for transient dynamic response analysis. Ph.D. Dissertation, University of Houston, 1990.

9) Oyo corporation : Suspension PS-logging unit manual, 1988.

10) Schnabel, P.B., Lysmer, J. and Seed, H.B.:SHAKE - A computer program for earthquake response analysis of horizontally layered sites, Report No. EERC 72-12, University of California, Berkeley, 1972. 
11) Wood, R.D.: In situ tests for foundation vibrations. Proceedings, In situ '86, ASCE Special Conference on Use of In situ Tests in Geotechnical Engineering, Blackburg, VA, ASCE, Geotechnical Special Publication 6 : 336-375, 1986.

(Received January 22, 1993)

ダウンホール法とサスペンション法による原位置弾性波 速度の比較

亀井健史・大谷 順・中村嘉博

原位置における弾性波速度を求めるために,さまざまなPS検層法が実施されているが,各手 法によって得られるP波およびS波速度の比較や, 原位置試験結果と室内試験結果との対応性 について論じられたものは少ない. 本論文では, 日本において最も一般的に実施されている ダウンホール法と比較的最近開発されたサスペンション法を取り上げ, 同じ孔内で行なわれ た両試験結果について比較検討している。また, 原位置試験と室内試験によって得られた結 果の対応性についても検討した。 